\title{
Taxonomic remarks on the genus Cupiennius Simon (Araneae, Ctenidae) and description of $C$. vodou sp. nov. from Haiti
}

\author{
Antonio D. Brescovit ${ }^{1} \&$ Daniele Polotow ${ }^{1,2}$ \\ ${ }^{1}$ Laboratório de Artrópodes, Instituto Butantan. Avenida Vital Brazil 1500, 05503-900 São Paulo, São Paulo, Brasil. \\ E-mail: adbresc@terra.com.br \\ 2 Departamento de Zoologia, Instituto de Biociências, Universidade de São Paulo. Caixa Postal 11461, 05422-970 São \\ Paulo, São Paulo, Brasil. E-mail: danielepolotow@butantan.gov.br
}

\begin{abstract}
Ctenus bimaculatus Taczanowski, 1874, is removed from the synonymy of Ancylometes rufus (Walkenaer, 1837) and transferred to the genus Cupiennius Simon, 1891, in which it is placed as a senior synonym of Cupiennius celerrimus Simon, 1891. New records are presented for $C$. bimaculatus (TACZANOWSKI 1874) and a new species, $C$. vodou, is described from Haiti.
\end{abstract}

KEY WORDS. Brazil, Ctenus, Ancylometes, spiders, taxonomy.

\begin{abstract}
RESUMO. Notas taxonômicas sobre o gênero Cupiennius Simon (Araneae, Ctenidae) e descrição de $C$. vodou sp. nov. do Haiti. Ctenus bimaculatus Taczanowski, 1874, é removido da sinonímia de Ancylometes rufus (Walkenaer, 1837) e transferido para o gênero Cupiennius Simon, 1891, no qual é considerado sinônimo sênior de Cupiennius celerrimus SIMON, 1891. São apresentados novos registros para C. bimaculatus (Taczanowski, 1874) e uma nova espécie, C. vodou, é descrita para o Haiti.

PALAVRAS CHAVE. Aranhas, Brasil, Ctenus, Ancylometes, taxonomia.
\end{abstract}

Through the courtesy of Dr. Jacek Swedo of the Polska Academy of Sciences, we have recently had the opportunity to examine the type-specimen of Ctenus bimaculatus described by TACZANOWSKi (1874), based on a female from Uassa, French Guyana. This species was synonymized with Ancylometes rufus (Walkenaer, 1837) by HöFer \& BREsCovit (2000).

To our surprise, the examination of the type revealed that the speciemen is an immature female, in the penultimate instar, of Cupiennius celerrimus SIMON, and not a synonym of $A$. rufus as published in HÖFER \& BRESCOVIT (2000). Thus, in this paper Ctenus bimaculatus TACZANOWSKI is removed from the synonymy of Ancylometes rufus and transferred to the genus Cupiennius in which it is placed as a senior synonym of Cupiennius celerrimus Simon. New records are presented from Brazil, Guyana and Ecuador and a new species is described from Haiti, based on material deposited in the collection of the Instituto Butantan. This is the second record of a Cupiennius species in Haiti, the first being C. salei (KeyserLING), a widespread species also known from USA and Central America (LAснмuтH et al. 1985).

The material examined belongs to the following institutions (abbreviation and curators in parenthesis): Instituto Butantan, São Paulo (IBSP, A.D. Brescovit); Museu Nacional do Rio de Janeiro, Rio de Janeiro (MNRJ, A.B. Kury); Museu Paraense
Emílio Goeldi, Belém (MPEG, A.B. Bonaldo); Polska Academy of Sciences, Warsaw (PAN, J. Swedo). The format of descriptions basically follow HöFer et al. (1994). All measurements are in millimeters. The epigynum was dissected and immersed in clove oil to study internal structures (LeVI 1965).

\section{RESULTS}

\section{Cupiennius bimaculatus (Taczanowski, 1874), sp. reval.}

Ctenus bimaculatus Taczanowski, 1874: 92 (Immature female, penultimate instar, holotype from Uassa, French Guiana, Jelski leg., deposited in PAN, examined); Platnick, 2005.

Cupiennius celerrimus Simon, 1891: 111 (Syntypes male and female from Tefé, Amazonas, Brazil, should be in the Muséum National d'Histoire Naturelle, Paris, not found, probably lost); Mello-Leitão, 1936: 600; Roewer, 1955: 625; Bonnet, 1956: 1293; Lucas, 1964: 127, 133; Lachmuth et al., 1985: 361; Brescovit \& Eickstedt, 1995; Barth \& Cordes, 1998:137140; Platnick, 2005. Syn. nov.

Ctenus cuminamensis Mello-Leitão, 1930: 64, figs 24-25 (holotype female from Cuminá, Amazonas, Brazil, deposited in MNRJ number 144, not re-examined); Roewer, 1955: 649; Bonnet, 1956: 1279; Brescovit \& Eickstedt, 1995: 642 (Syn.); Platnick, 2005. 

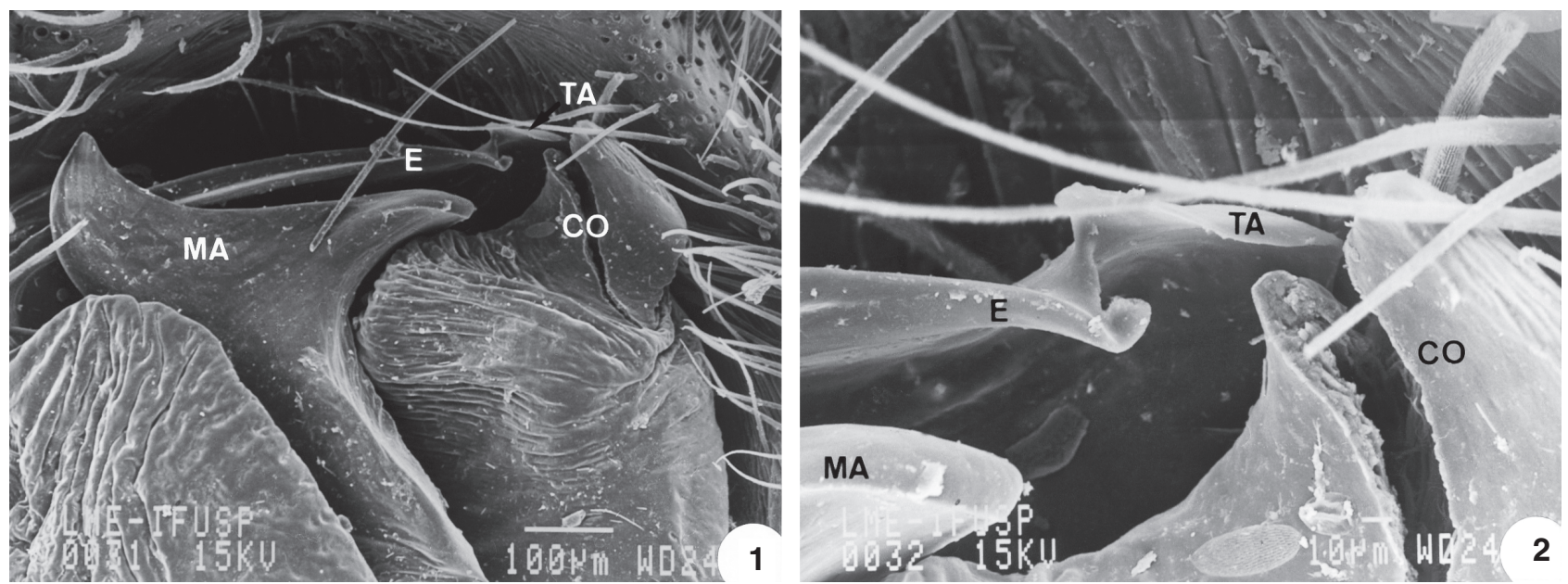

Figures 1-2. Cupiennius vodou sp. nov.: (1) male, left palp, ventral view; (2) terminal apophysis of the embolus, detail, ventral view. Scale lines: $0.25 \mathrm{~mm}$. (CO) Conductor, (E) embolus, (MA) median apophysis, (TA) terminal apophysis of the embolus.

Ctenus cuminaensis [sic]: Mello-Leitão, 1936: 7, Fig. 5 (lapsus). Ancylometes bimaculatus: Höfer \& Brescovit, 2000: 337; Platnick, 2005.

Synonymy. The type specimen of $C$. bimaculatus is an immature female in the penultimate instar and, although nothing can be said on the genitalia, presents the same basic coloration pattern observed in C. celerrimus. As described by BRESCOVIT \& EICKSTEDT (1995: 644) the coloration pattern of the abdomen is dorsally (brownish-green) green-brown, with almost black transversal bands in the anal tubercle. Ventrally it is yellow with a narrow median longitudinal dark gray band.

New records. Ecuador, Morona-Santiago: Los Tayos, 1 male, 1 female, 1-14.VII.1976, P. Ashmole leg. (IBSP 4314; 4315); BRAZIL, Roraima: Posto Xitei/Xidia, Área Indígena Yanomami, (02³6'25"S, 6352'18”W), 1 male, 5-13.XII.1998, P. Torres leg. (IBSP 23521); Rondônia: Rio Jamari, Usina Hidrelétrica de Samuel, 1 female 1 immature, XII.1980, Equipe Butantan leg. (IBSP 5670; 7181); Ouro Preto do Oeste, 1 female, 4-22.X.1986, J. Becker leg. (MNRJ 13436); Amazonas: Manicoré, Barreira do Matupiri, 1 female, 18.IV.1996, Equipe IBSP/SMNK leg. (IBSP 8871); Pará: Almeirin, Reserva do Quaruba, 2 females, 5.XII.2002, A.L. Prudente leg. (MPEG 1162); Novo Progresso, Serra do Cachimbo, Campo de Provas Brigadeiro Veloso $\left(09^{\circ} 22^{\prime} 02,9^{\prime \prime}\right.$ S, 5501'11,9”W), 1 female, 8.IV-25.V.2003, A.B. Bonaldo et al. leg. (MPEG 1413; 1416; 1406); Vitória do Xingu, 1 male, 28.XI.2000 (MPEG); Belém, 1 female, VII.1984, A. Cerrutti leg. (MNRJ); Paraíba: Mamanguape, APA de Mamanguape, 6 males, 11 females, 2001, C. Arzabe leg. (IBSP $39317-$ 39322; 39324-39326; 39328); Pernambuco: Tamandaré, Reserva Biológica de Saltinho, 1 male, 27.IV.1999, M.F. da Silva leg. (IBSP 39592); Goiana, Usina Maravilha, 2 females, 16.VI. 2003, S.C. Dias leg. (IBSP 41389); Alagoas: Murici, Estação Ecológica de Murici $\left(09^{\circ} 15^{\prime}\right.$ S, $\left.35^{\circ} 51^{\prime} \mathrm{W}\right), 4$ males, 2 females, 13-22. IX.2003,
Equipe Biota leg. (IBSP 52226-52231); Mato Grosso: Vila Bela da Santíssima Trindade, 1 female, 07-22.IX.1997, M. Calleffo leg. (IBSP 13325); Diamantina, Alto Rio Arinos, 1 female, X.1983, A. Cerrutti leg. (MNRJ 13439).

Distribution. The distribution range of this species, known from Venezuela and Brazil, is amplified to Guyana and Ecuador.

\section{Cupiennius vodou sp. nov.}

Figs 1-7

Types. Male holotype from Miragoane, Centre, Haiti, Jan.1974, R. Bell leg., deposited in IBSP 47611; 1 male and 1 female paratypes, from Derivieux, near Miragoane, Centre, Haiti, 19.XII.1976, M. Langworthy leg., deposited in IBSP 47610 and 47612, respectively.

Etymology. The specific name "vodou" originates from the term "vodun" of the fon's (an African tribe brought to Haiti during the French colonization) language and means "god" or "spirit" and is a name of a popular religious cult in the countryside community of the Haiti.

Diagnosis. Males of Cupiennius vodou sp. nov. resemble those of C. salei (Keyserling) by the morphology of the palpus bulb with similar median apophysis (LACHMUTH et al. 1985: 349, fig. 20), but are distinguished by the shorter conductor and narrow terminal apophysis of the embolus (Figs 1-4). Females resemble those of $C$. bimaculatus by the narrowed median septum (see BARTH \& CoRdes, 1998, fig. 14, as in C. celerrimus) but differs from this species by the median constriction and rounded distal area of the median septum (Fig. 6); and, internally, by the large copulatory ducts and smaller spermathecae (Fig. 7). The coloration of the ventral abdomen (Fig. 5) distinguish $C$. vodou sp. nov. from other Cupiennius species (see BARTH \& CORDES 1998: figs 6-12 to comparation).

Description. Holotype male. Carapace with light brown

Revista Brasileira de Zoologia 22 (3): 771-774, setembro 2005 


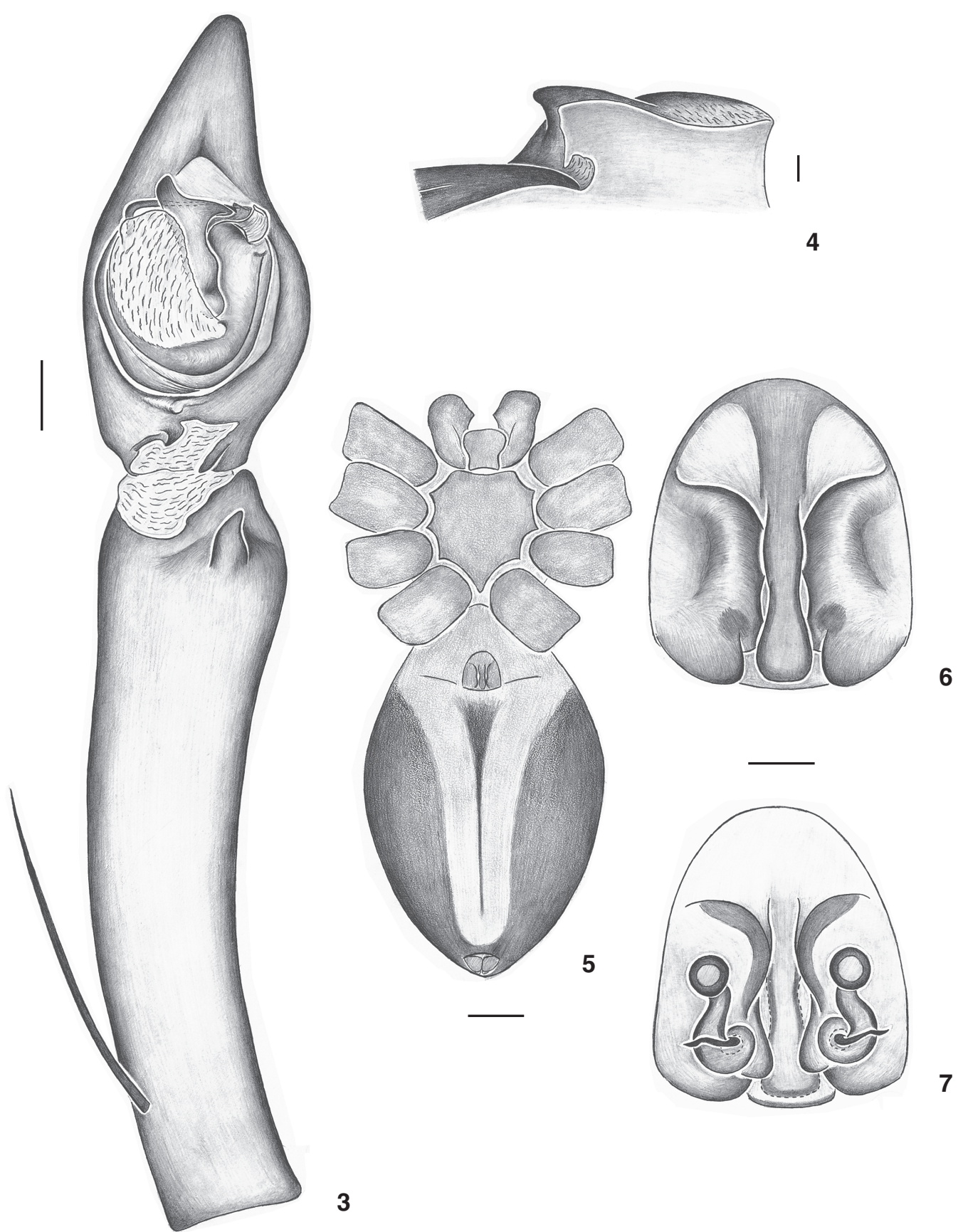

Figures 3-7. Cupiennius vodou sp. nov. (3-4) Male, left palp: (3) ventral view; (4) terminal apophysis of the embolus, detail, ventral view; (5) body, ventral view; (6-7) epigynum: (6) ventral view; (7) dorsal view. Scale lines: $0.25 \mathrm{~mm}$.

cephalic area. Chelicerae brown with longitudinal ventral dark brown bands. Labium, endites, sternum and legs light brown. Abdomen dorsally brown, with a median longitudinal lighter band, and two proximal black spots on the beside the dorsal band. Ventrally with a narrow longitudinal gray band and light brown lateral borders. Total length 23.68; carapace: 10.80 long, 9.40 wide. Clypeus 0.66 high, slightly wider than the AME diameter. Eye diameters and interdistances: AME 0.60; ALE 0.34; PME 0.78; PLE 0.78; AME-AME 0.38; AME-ALE 0.46; PME-PME 0.34; PME-PLE 0.50; ALE-PLE 0.50, AME-PME 0.26. Chelicerae 
with 3 promarginal teeth and 4 retromarginal denticles. Leg measurements: I - femur 13.30/patella 5.20/tibia 12.30/metatarsus 13.90/tarsus 4.70/total 49.40/II - 13.70/5.10/11.90/14.20/ 4.40/49.30/III - 12.05/4.50/8.20/12.00/3.60/40.35/IV - 13.70/ 4.70/11.50/16.00/4.30/50.20. Leg spination: tibia I v2-2-2-2, p1-1-0, r1-1-1, II v2-2-2-2, p1-1-0, r1-1-0, III v2-2-2, p1-1-0, r11-0, IV v2-2-2, p1-1-0, r1-1-0; metatarsus I v2-0-1m, p1-1-0, r11-1, II v2-2-1m, p1-1-0, r1-1-1, III v2-2-1m, p1-1-2, r1-1-2, IV v2-2-1m, p1-1-2, r1-1-2. Metatarsus and tarsus I-II-III with thick ventral scopulae, reduced in the articles of leg IV. Male palp long, curved and presenting a short distal tibial apophysis (Fig. 3). Bulb with proeminent median apophysis with elongated and conical terminal process. Conductor flattened with curved apex. Embolic apophysis curved and twist and presents a terminal apophysis (Figs 1-4).

Female (Paratype, IBSP 47612). Coloration pattern as in male, except carapace with dorsal longitudinal orange-brown band. Abdomen without the two black spots and ventral area slightly brown as shown on figure 5 . Total length 18.30; carapace: 7.40 long, 6.50 wide; Clypeus 0.40 high, as in male. Eye diameters and measurements: AME 0.44; ALE 0.16; PME 0.63; PLE 0.64; AME-AME 0.30; AME-ALE 0.50; PME-PME 0.48; PMEPLE 0.58; ALE-PLE 0.32; AME-PME 0.24. Chelicerae as in male. Leg measurements: I - femur 7.90/patella 3.30/tibia 8.50/metatarsus $8.20 /$ tarsus 3.10/total 31.00/II $-8.30 / 3.30 / 8.10 / 7.90 /$ 3.10/30.70/III - 7.50/2.50/6.00/6.10/2.50/24.60/IV - 8.30/2.90/ 7.40/8.80/3.10/30.30. Leg spination: tibia I-II v2-2-2-2, p1-1, r1-1, III v2-2-2, p1-1, r1-1, IV v2-2-2, p1-1, r1-1-1; metatarsus I v2-2-2, p1-1-1, r1-1-1, II v2-2-2, p1-1-0, r1-1-0, III v2-2-2, p1-11, r1-1-1, IV v2-2-2, p1-1, r1-1-1. Metatarsus and tarsus I-II-III with thick scopulae as in male. Epigynal plate oval. Median septum narrow, with a median constriction and rounded at tip. Lateral plate distaly directly, connected to the median septum forming a loop (as in "group b" from BARTH \& CORDES 1998: 137, fig. 14) and basally with rounded borders (Fig. 6). Internally with small spermathecae, larger copulatory ducts and narrow and sinuous fertilization ducts (Fig. 7).

Other material examined. None.

Distribution. Known only from Haiti.

\section{ACKNOWLEDGEMENTS}

We wish to thank Miguel Simó and Cristina A. Rheims for helpful suggestions on the manuscript and the staff of the Polska Academy of Sciences, Warsaw for the access to the type. This study was supported by CNPq and FAPESP (99/05446-8). This study is part of the BIOTA/FAPESP - The Biodiversity Vir- tual Institute Program (www.biotasp.org.br).

\section{REFERENCES}

Barth, F.G. \& D. Cordes. 1998. Cupiennius remedius new species (Araneae, Ctenidae), and a key for the genus. Journal of Arachnology, Indiana, 26 (2): 133-141.

Bonnet, P. 1956. Bibliographia araneorum. Toulouse, 2 (2): 919-1926.

BResCovit, A.D. \& V.R.D. von EICKSTEDT. 1995. Ocorrência de Cupiennius Simon na América do Sul e redescrição de Cupiennius celerrimus Simon (Araneae, Ctenidae). Revista Brasileira de Zoologia, Curitiba, 12: 641-646.

HÖFER, H. \& A.D. Brescovit. 2000. A revision of the Neotropical spider genus Ancylometes Bertkau (Araneae: Pisauridae). Insect Systematics and Evolution, Copenhagen, 31: 323-360.

Höfer, H.; A.D. Brescovit \& T. Gasnier. 1994. The wandering spiders of the genus Ctenus (Ctenidae, Araneae) of Reserva Ducke, a rainforest reserve in central Amazonia. Andrias, Karlsruhe, 13: 81-98.

Lachmuth, U., M. Grasshoff \& F.G. Barth. 1985. Taxonomische Revision der Gattung Cupiennius Simon 1891 (Arachnida: Araneae: Ctenidae). Senckenbergiana biologica, Frankfurt, 65: 329-372.

Levi, H.W. 1965. Techniques for the study of spider genitalia. Psyche, Cambridge, 72: 152-158.

LuCAS, S. 1964. Sôbre a posição sistemática de algumas espécies de aranhas verdadeiras do gênero Cupiennius, Simon 1891, da família Ctenidae, em relação ao gênero Ancylometes, Bertkau 1880, da família Pisauridae. Memórias do Instituto Butantan, São Paulo, 31: 127-134.

Mello-Leitão, C.F. DE. 1930. Aranhas do Cuminá. Archivos do Museu Nacional, Rio de Janeiro, 32: 51-75.

Mello-Leitão, C.F. DE. 1936. Contribution à l'etude des Ctenides du Bresil. Festschrift Strand, Riga, 1: 1-31

Platnick, N. I. 2005. The world spider catalog, version 5.0. American Museum of Natural History. Available on the Wide World Web at http://research.amnh.org/entomology/ spiders/catalog/index.html. Accessed in 8.VI.2005.

Roewer, C.F. 1955. Katalog der Araneen von 1758 bis 1940, bzw. 1954. Bruxelles, 2: 1-1751.

SIMON, E. 1891. Descriptions de quelques arachnides du Costa Rica communiqués pa M. A. Getaz (de Genève). Bulletin de la Société Zoologique de France, Paris, 16: 109-112.

TACZANOWSKI, L. 1874. Les aranéides de la Guyane française. Horae Societatis Entomologicae Rossicae, S. Petersburg, 10: 56-115.

Received in 18.I.2005; accepted in 23.VIII.2005.

Revista Brasileira de Zoologia 22 (3): 771-774, setembro 2005 